\title{
Pengaruh Asset Growth, Sales Growth, Net Profit Margin, Current Ratio dan Debt To Equity Ratio terhadap Dividend Payout Ratio pada Perusahaan yang Termasuk dalam Indeks Lq 45 Tahun 2013 - 2016
}

\author{
${ }^{1}$ Mufidah \\ ${ }^{1}$ Fakultas Ekonomi , Universitas Batanghari
}

\begin{abstract}
This research aimed to examine theinfluence of Asset Growth, Sales Growth, Net Profit Margin, Current Ratio , debt to equity ratio on dividend payout ratio of the Company listed in indeks $L Q 45$. The data used in this research is 16 companies for the period of 2013 - 2016 . The method of data analysis uses multiple linear regression. The result indicates that simultaneously the variable of Asset Growth, Sales Growth, Net Profit Margin, Current Ratio, debt to equity ratio significant affect divident payout ratio. These independent variables are able to explain the effect dividend payout ratio amount of $83,7 \%$ while the remains $16,3 \%$ is determined by other factors. Partially all of the variables affect dividend payout ratio except of the variable of net profit margin. Sales growth had positive effect on dividend payout ratio. Beside that aset growth, current ratio and debt to equity ratio have a negative effect on dividend payout ratio.
\end{abstract}

Keywords: dividend payout ratio ,Sales Growth

\section{PENDAHULUAN}

Kebijaksanaan dividen menentukan berapa banyak dari keuntungan harus dibayarkan kepada pemegang saham dan berapa banyak yang harus ditanam kembali di dalam perusahaan. Laba yang ditahan merupakan salah satu sumber dana yang terpenting untuk membiayai pertumbuhan perusahaan, tetapi dividen membentuk arus uang keluar ke tangan pemegang saham. Jika perusahaan mempunyai kas yang kecil atau jika posisi likuiditasnya buruk, maka pembagian dividen atau Tingkat pembayaran dividen (dividend payout ratio) sulit dilaksanakan atau jika dipaksakan maka akan terjadi utang deviden dan makin memperburuk posisi likuiditas perusahaan .

Peningkatan hutang akan mempengaruhi besar kecilnya laba bersih yang tersedia bagi para pemegang saham termasuk dividen yang akan diterima, oleh karena itu semakin rendah debt to equity makaakan semakin tinggi kemampuan perusahaan untuk membayar seluruh kewajibannya. Semakin besar proporsi hutang maka akan semakin besar pula jumlah kewajibannya. Peningkatan hutang pada gilirannya akan mempengaruhi besar kecilnya laba bersih yang tersedia bagi para pemegang saham termasuk dividen yang akan diterima, karena kewajiban tersebut lebih diprioritaskan daripada pembagian dividen (Baert dan Vennet, 2009).

Perusahaan yang dipilih untuk menjadi obyek penelitian ini adalah perusahaan non keuangan yang masuk dalam indeks saham LQ 45 berturut - turut untuk periode 2013 - 2016. Pemilihan perusahaan berdasarkan indeks saham LQ 45 ini karena perusahaan ini telah dinilai sebagai perusahan yang besar yang mudah memperoleh dana dari pasar bursa yang umumnya memiliki laba stabil dan tinggi

Pengaruh Asset Growth, Sales Growth, Net Profit Margin, Current Ratio dan Debt To Equity Ratio terhadap Dividend Payout Ratio pada Perusahaan yang Termasuk dalam Indeks Lq 45 Tahun $2013-$ 2016 
yang dapat membagi dividen besar dibandingkan perusahaan yang lebih kecil namun ternyata perusahaan-perusahaan ini mempunyai dividen payout ratio yang berfluktuasi cukup tajam.Rata-rata Asset Growth, Sales Growth, net profit margin ( NPM), Rasio Lancar (Current Ratio), debt to equity (DER) dan dividend payout ratio (DPR)seperti terlihat dalam Tabel 1 berikut ini:

\section{Tabel 1}

Rata- Rata Asset Growth, Sales Growth, NPM, Current Ratio, DER dan DPR

\begin{tabular}{lrrrrr}
\hline \multicolumn{1}{c}{ Variabel } & \multicolumn{4}{c}{ Tahun } & \multicolumn{1}{c}{ Rata- Rata } \\
& $\mathbf{2 0 1 3}$ & $\mathbf{2 0 1 4}$ & $\mathbf{2 0 1 5}$ & $\mathbf{2 0 1 6}$ & \\
\hline Asset Growth & 14,75 & 19,29 & 17,11 & 13,57 & 16,18 \\
Sales Growth & 12,03 & 8,12 & 1,79 & 6,09 & 7,01 \\
NPM & 13,41 & 14,54 & 11,72 & 12,77 & 13,11 \\
CR & 224,49 & 202,06 & 293,58 & 210,59 & 232,68 \\
DER & 1,07 & 1,06 & 0,57 & 0,90 & 0,9 \\
DPR & 46,31 & 41,49 & 4,72 & 67,83 & 40,08 \\
\hline
\end{tabular}

\section{Sumber : Data diolah}

Dari tabel 1 diatas, terlihat bahwa rata - rata tingkat pertumbuhan penjualan ( sales growth) selama empat periode tahun yang sama yaitu $7,01 \%$, lebih rendah daripada tingkat margin laba bersih (npm) 13,11\%. Hal ini menunjukkan indikasi pengendalian yang lebih ketat atas beberapabeban operasi . Pengendalian biaya lebih lanjut akan memungkinkan perusahaan yang termasuk indeks LQ 45 untuk terus meningkatkan profitabilitas dan melebihi standar industri sehingga tingkat dividen payout $(40,08 \%)$ menjadi cukup tinggi.Ini menandakan bahwa industri ini memilih untuk membayarkan sejumlah besar dari labanya.MenurutKadir (2010) menyatakan bahwa perusahaan yang mempunyai tingkat profitabilitas, likuiditas dan aktivitas yang tinggi akan memampukan perusahaan tersebut membagikan dividen kepada investor dalam jumlah tinggi sedangkan perusahaan yang mempunyai tingkat leverage berhubungan negatif dengan tingkat pengembalian investasi berupa dividen bagi investor, karena tingkat leverage menunjukkan bahwa perusahaan akan melunasi kewajibannya terlebih dahulu dari laba yang diperoleh sehingga dividen yang dibagikan ke investor menjadi kecil. (Ahmadi dan Alhudhori, 2017)

Menurut kraft et al., (2013) hubungan debt to equity (DER) terhadap DevidendPayout Ratio ( DPR) adalah negatif , namun pada tabel 1 terdapat perbedaan yaitu dari tahun 2013- 2016 dimana peningkatan DER juga diikuti oleh peningkatan DPR begitu juga sebaliknya dimana penurunan DER diikuti oleh penurunan DPR. Selain itu Menurut Kraft el et., ( 2013 ) hubungan antara Profitability dan DPR adalah positif, namun pada tabel 1 terlihat bahwa dari tahun 2013 - 2014 profitability yang diproksikan dengan Net Profit Margin (NPM) dimana NPM mengalami peningkatan namun DPR justru mengalami penurunan .

Berdasarkan Penelitian-penelitian sebelumnya Arifin dan asyik (2015) dimana profitabilitas dan likuiditas tidak berpengaruh signifikan terhadap kebijakan deviden dan growth potensial berpengaruh signifikan negative terhadap kebijakan deviden. Begitu juga dengan penelitian kadir ( 2010) dan deitiana (2013) dimana variabel

Pengaruh Asset Growth, Sales Growth, Net Profit Margin, Current Ratio dan Debt To Equity Ratio terhadap Dividend Payout Ratio pada Perusahaan yang Termasuk dalam Indeks Lq 45 Tahun $2013-$ 2016 
current ratio yang merupakan salah satu dari ratio likuiditas tidak memberikan pengaruh terhadap devidend payout ratio .

Berdasarkan latar belakang masalah dan penelitian terdahulu, maka rumusan masalah dari penelitian ini adalah sebagai berikut: (1) Apakahasset growth, sales growth, NPM, CR, dan DER berpengaruh secara simultan terhadap devidend payout ratio? (2) Apakah asset growth, sales growth, NPM, CR, dan DER berpengaruh secara parsial terhadap devidend payout ratio ? . Berdasarkan latar belakang dan perumusan masalah yang diuraikan diatas maka tujuan penelitian adalah sebagai berikut : (1) Untuk menganalisis pengaruh asset growth, sales growth, NPM, CR, dan DER secara simultan terhadap devidend payout ratio (2) Untuk menganalisis pengaruh asset growth, sales growth, NPM, CR, dan DER secara parsial terhadap devidend payout ratio.

\section{Deviden Payout Ratio}

Pengertian dividen menurut Brigham dan Houston ( 2012 ) adalah distribusi laba kepada pemegang investasi ekuitas sesuai dengan proporsi mereka dan jenis modal tertentu.Alexander, et al. (1993) dalam (Prihantoro, 2003), mendefinisikan kebijakan deviden sebagai kebijakan yang berhubungan dengan pembayaran deviden kepada pihak perusahaan. Jika manajemen meningkatkan porsi laba perlembar saham yang dibayarkan sebagai deviden, maka mereka dapat meningkatkan kesejahteraan para pemegang saham. Hal ini menyarankan bahwa keputusan jumlah deviden yang di bayarkan merupakan hal yang sangat penting.

\section{Asets Growth terhadap Deviden Payout Ratio}

Pertumbuhan total aset sangat berpengaruh dalam penentuan kebijakan deviden karena semakin besar pertumbuhan aset perusahaan, maka perusahaan akan lebih memilih menggunakan laba yang diperoleh untuk membiayai ekspansi daripada menggunakannya untuk membayar deviden. Pertumbuhan perusahaan yang tinggi akan membuat perusahaan menggunakan sebagian besar labanya untuk membiayai pertumbuhannya, sehingga laba yang tersisa untuk dibagikan sebagai deviden kepada para pemegang saham akan semakin kecil. Selain itu menurut teori residual dividen, perusahaan akan membayar dividennya jika tidak memiliki kesempatan investasi yang menguntungkan, sehingga terdapat hubungan negatif antara pertumbuhan aset dan pembayaran dividen.

Dalam penelitian Silviana, dkk (2014) menyatakan bahwa pertumbuhan asset perusahaan berpengaruh negatif dan signifikan terhadap devidend payout ratio.Selain itu dalam penelitian Nadjibah (2008) juga memberikan hasil bahwa asset growth berpengaruh secara negatif dan signifikan terhadap devidend payout ratio. Dengan demikian setiap kenaikan Asset growth akan mengakibatkan menurunnya devidend payout ratio. Berdasarkan uraian yang telah disebutkan, dapat dibuat hipotesis sebagai berikut:

$\mathrm{H}_{1}$. Aset Growth Berpengaruh Negative Terhadap Dividen Payout Ratio

\section{Sales Growth terhadap Deviden Payout Ratio}

Salah satu dasar untuk menentukan kebijakan deviden adalah bahwa manajer perusahaan harus menggunakan metode penjualan karena pertumbuhan penjualan 
yang tinggi mencerminkan laba yang tinggi .Tingkat penjualan yang meningkat akanmencerminkan pendapatan perusahaan yang meningkat pula, sehingga perusahaan memperoleh dana yang tinggi. Oleh karena itu perusahaan mampu membayarkan deviden kepada para pemegang saham. Menurut Laksono (2006) untuk mengetahui pengaruh sales growth terhadap devidend payout ratio pada perusahaan multi national company (MNC) dan domestic corporation, menunjukkan bahwa sales growth memiliki pengaruh positif terhadap keputusan deviden. Pengaruh positif memberikan arti bahwa semakin meningkatnya pertumbuhan suatu perusahaan, maka deviden yang dibagikan kepada investor semakin meningkat. Berdasarkan uraian yang telah disebutkan, dapat dibuat hipotesis sebagai berikut:

$\mathrm{H}_{2}$. Sales Growthberpengaruh positif terhadapdividen payout ratio

\section{Net Profit Margin terhadapDeviden Payout Ratio}

Profitabilitas adalah kemampuan perusahaan menghasilkan laba (profit). Laba inilah yang akan menjadi dasar pembagian dividen perusahaan, apakah dividen tunai ataupun dividen saham. Untuk mengukur profitabilitas salah satunya mengunakan net profit margin atau margin laba bersih.Menurut Kasmir (2010) margin laba bersih merupakan keuntungan dengan membandingkan antara laba setelah bunga dan pajak dibandingkan dengan penjualan. Penelitian Yasa dan wirawati ( 2016 ), menunjukkan bahwa variabel net profit margin berpengaruh positif terhadap dividend payout ratio .Berdasarkan uraian yang telah disebutkan, dapat dibuat hipotesis sebagai berikut:

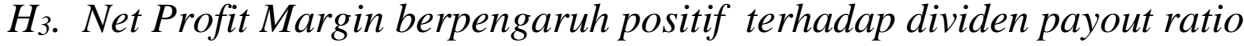

\section{Current Ratio terhadapDeviden Payout Rate}

Menurut Sartono ( 1998) dalam deitiana (2013) Current ratio (CR) merupakan alat ukur bagi kemampuan likuiditas yaitu kemampuan untuk membayar hutang yang segera harus dipenuhi dengan aktiva lancar yang dimilikinya.Jika perusahaan memiliki kas kecil, maka pembagian dividen sulit dilaksanakan atau jika perusahaan posisi likuiditas buruk, misalnya ratio lancar kurang dari 100 persen maka pembagian deviden . Dari tabel 1 terlihat bahwa Current ratio berfluktuasi naik turun dan Semakin besar CR yang dimilikinya menunjukkan besarnya kemampuan perusahaan dalam memenuhi kebutuhan operasionalnya terutama modal kerja yang sangat penting untuk menjaga kinerja perusahaan . Hal ini terlihat pada tahun 2015 CR naik menjadi $293,58 \%$ sedangkan Dividen payout ratio turun menjadi 4,72 \% Dari hasil penelitian kadir ( 2010) dan deitiana ( 2013 ) bahwa Current ratio tidak memberikan pengaruh yang signifikan. Pada Penelitian Yasa dan Wirawati memberikan hasil bahwa current ratio berpengaruh negatif terhadap Dividen payout ratio. Berdasarkan uraian yang telah disebutkan, dapat dibuat hipotesis sebagai berikut:

H. Current ratio berpengaruhnegative terhadap dividen payout ratio

\section{Debt To Equity Ratio terhadapDeviden Payout Ratio}

Peningkatan hutang akan mempengaruhi laba bersih yang tersedia bagi para pemegang saham termasuk dividen yang akan diterima. Ismiyanti dan Hanafi, (2004) mengungkapkan debt to equity ratio (DER) mencerminkan kemampuan perusahaan 
dalam memenuhi seluruh kewajibannya, yang ditunjukkan oleh berapa bagian modal sendiri yang digunakan untuk membayar hutang, DER yang tinggi maka DPR menurun (Nitta, 2006). Semakin rendah DER akan semakin tinggi kemampuan perusahaan untuk membayar seluruh kewajibannya. Semakin besar proporsi hutang yang digunakan untuk struktur modal suatu perusahaan, maka semakin besar pula jumlah kewajibannya. Peningkatan hutang akan mempengaruhi besar kecilnya laba bersih yang tersedia bagi para investor termasuk dividen yang akan diterima, karena kewajiban tersebut lebih diprioritaskan daripada pembagian dividen (Kraft et al., 2013). Ismiyanti dan Hanafi, (2004) mengungkapkan bahwa semakin tinggi DER, berarti komposisi hutang juga semakin tinggi, sehingga akan berakibat pada semakin rendahnya kemampuan perusahaan untuk membayarkan dividen. Perumusan hipotesis 3 didukung oleh 3 penelitian terdahulu yaitu: Ismiyati dan Hanafi, (2004); Nitta (2006); Kraft et al., (2013), dimana ketiga penelitian tersebut menunjukkan hasil bahwa debt to equity ratio berpengaruh negatif terhadap DPR. Berdasarkan uraian yang telah disebutkan, dapat dibuat hipotesis sebagai berikut:

$\mathrm{H}_{5}$. Debt to equity berpengaruh negatif terhadap dividen payout ratio

\section{METODE PENELITIAN}

Jenis data yang digunakan dalam penelitian ini adalah data sekunder. Metode pengumpulan data yang digunakan yaitu metode dokumentasi yang merupakan metode pengumpulan data dengan cara mempelajari catatan-catatan atau dokumen. Data yang digunakan dalam penelitian ini diperoleh dari laporan keuangan perusahaan yang termasuk dalam perusahaan yang termasuk dalam indeks LQ 45 yang dipublikasikan oleh Bursa Efek Indonesia (BEI) melalui situs www.idx.co.iddan annual report perusahaan yang diambil dari website masing- masing perusahaan.

\section{Populasi dan Sampel}

Populasi pada penelitian ini adalah perusahaan yang terdaftar di BEI dan tercantum dalam indeks LQ 45dari tahun 2013 sampai tahun 2016. Alasannya adalah, Index LQ45 dibuat dan diterbitkan oleh Bursa Efek Indonesia (www.idx.co.id). Indeks ini terdiri dari 45 saham dengan likuiditas (liquid) tinggi yang diseleksi melalui beberapa kriteria pemilihan. Selain penilaian atas likuiditas, seleksi atas saham-saham tersebut juga mempunyai kapitalisasi pasar yang cukup besar. Sedangkan sampel dalam penelitian ini diambil dengan menggunakan metode purposive sampling, yaitu teknik penentuan sampel dengan pertimbangan tertentu.Adanya pengusulan aturan regulasi pembatasan besaran devidend payout ratio perbankan dari Bank Indonesia untuk tahun - tahun mendatang, membuat pemilihan objek pemilihan sampel menjadi perusahaan non finansial.Adapun kriteria yang diambil menjadi sampel adalah perusahaan non finansial yang terdaftar di LQ 45 secara berturut - turut dari tahun 2013 sampai tahun 2016 dan membayarkan devidennya secara berturut - turut dari tahun 2013 sampai tahun 2016. Tabel 2 berikut di bawah ini adalah nama -nama perusahaan yang menjadi sampel penelitian

Pengaruh Asset Growth, Sales Growth, Net Profit Margin, Current Ratio dan Debt To Equity Ratio terhadap Dividend Payout Ratio pada Perusahaan yang Termasuk dalam Indeks Lq 45 Tahun 2013 2016 
Tabel 2

Nama - Nama Perusahaan Yang Menjadi Sampel Penelitian

\begin{tabular}{cll}
\hline No & Kode Saham & \multicolumn{1}{c}{ Nama Perusahaan } \\
\hline 1 & Adro & Adaro Energy Tbk \\
2 & Akra & AKR Corporindo Tbk \\
3 & ASII & Astra International Tbk \\
4 & BSDE & Bumi Serpong Damai Tbk \\
5 & CPIN & Charoen Pokphand Indonesia Tbk \\
6 & GGRM & Gudang Garam Tbk \\
7 & ICBP & Indofood CBP Sukses Makmur Tbk \\
8 & INDF & Indofood Sukses Makmur Tbk \\
9 & INTP & Indocement Tunggal Prakasa Tbk \\
10 & KLBF & Kalbe Farma Tbk \\
11 & LSIP & PP London Sumatera Tbk \\
12 & PTBA & Tambang Batubara Bukit Asam ( Persero ) tbk \\
13 & UNTR & United Tractors Tbk \\
14 & UNVR & Unilever Indonesia Tbk \\
15 & WIKA & Wijaya Karya ( Persero) Tbk \\
16 & WSKT & Waskita karya ( Persero ) Tbk \\
\hline
\end{tabular}

Sumber : Data Diolah

\section{Pengukuran Variabel}

Variabel yang digunakan dalam penelitian ini, terdiri dari variabel independen yaitu aset asset growth, sales growth, Net profit margin (NPM), Current ratio (CR) dan debt to equity rate (DER) dan variabel dependen yaitu deviden payout ratio (DPR). Berikut tabel 3 dibawah ini adalah operasional masing - masing variabel .

Tabel 3

Operasional Variabel.

\begin{tabular}{|c|c|c|}
\hline Variabel & Rumus & Skala \\
\hline $\begin{array}{l}\text { dividend payout ratio) } \\
\text { (Y) }\end{array}$ & $D P R=\frac{\text { dividen tunai per saham }}{\text { laba per saham }}$ & Rasio \\
\hline Aset Growth $\left(\mathrm{X}_{1}\right)$ & $A G=\frac{\text { Total Aset }_{t}-\text { Total Aset }_{t-1}}{\text { Total Aset }_{t-1}}$ & Rasio \\
\hline Sales Growth $\left(\mathrm{X}_{2}\right)$ & $S G=\frac{\text { Total Sales }_{t}-\text { Total Sales }_{t-1}}{\text { Total Sales }_{t-1}}$ & Rasio \\
\hline net profit margin $\left(\mathrm{X}_{3}\right)$ & $N P M=\frac{\text { Laba Bersih }}{\text { Penjualan }}$ & Rasio \\
\hline Current ratio $\left(\mathrm{X}_{4}\right)$ & $C R=\frac{\text { Aset Lancar }}{\text { Kewajiban Lancar }}$ & Rasio \\
\hline Debt Equity Ratio $\left(\mathrm{X}_{5}\right)$ & $D E R=\frac{\text { Total Kewajiban }}{\text { Ekuitas Pemegang saham }}$ & Rasio \\
\hline
\end{tabular}




\section{Metode Analisis Data}

Metode analisis data yang dipergunakan dalam penelitian ini adalah metode analisis data kuantitatif yang diolah dengan program komputer Statistical Package For Social Science (SPSS) 22. Metode analisis data yang dilakukan pada penelitian ini meliputi statistik deskriptif, uji asumsi klasik, dan kemudian dilakukan pengujian hipotesis. Pengujian hipotesis dalam penelitian ini menggunakan analisis regresi linier berganda. Model persamaan regresi liner berganda yang dibangun dalam penelitian ini adalah:

$\mathrm{DPR}=\alpha+\beta_{1} . \mathrm{AG}_{\mathrm{it}}+\beta_{2} . \mathrm{SG}_{\mathrm{it}}+\beta_{3} . \mathrm{NPM}_{\mathrm{it}}+\beta_{4} . \mathrm{CR}_{\mathrm{it}}+\beta_{5} . \mathrm{DER}_{\mathrm{it}}+\mathrm{e}$.

Keterangan: DPR : Devident Payout Rate; AG : Asset Growth; SG : Sales Growth; NPM : Net Profit Margin; CR : Current Ratio; DER : Debt to Equity ratio; $\alpha$; Konstanta; $\beta_{1}-\beta_{5}$ : Koefisien Regresi; e : Error

\section{HASIL PENELITIAN}

Uji Asumsi Klasik

Uji normalitas dapat digunakan untuk menguji apakah dalam sebuah model persamaan regresi variabel pengganggu atau residual memiliki distribusi normal (Ghozali, 2011). Salah satu uji normalitas yang digunakan dalam penelitian ini adalah uji statistik Kolmogorov-Sminov (K-S). Hasil uji statistik pada tabel 5. KolmogorovSminov (K-S) menunjukkan bahwa nilai Asymp. Sig. (2-tailed) sebesar 0.200. Ghozali (2011) berpendapat bahwa jika nilai signifikansi lebih besar dari $(>0,05)$ maka dapat dikatakan bahwa data tersebut normal.

Tabel 4

One-Sample Kolmogorov-Smirnov Test



Uji multikolinearitas bertujuan untuk menguji apakah model regresi ditemukan adanya korelasi antar variabel bebas (independen). Nilai cutoff yang umum dipakai untuk menunjukkan adanya multikolonieritas adalah nilai tolerance $\leq 0.10$ atau sama dengan nilai VIF $\geq 10$ (Ghozali, 2011). Adapun hasil uji multikolinieritas pada tabel 6 dibawah ini, nilai tolerance dan VIF (Variance Inflation Factor) variabel AG sebesar 0,589 dan 1,699, variabel SG sebesar 0,617 dan 1,621, variabel NPMsebesar 0,674 dan 1,484. Variabel CR sebesar 0,647 dan 1,546 dan Variabel DER sebesar 0,463 dan 
2,160 Dengan demikian model persamaan regresi dalam penelitian bebas dari gejala multikolinearitas.

Tabel 6

Koefisien

\begin{tabular}{|c|c|c|c|c|c|c|c|}
\hline \multirow{2}{*}{\multicolumn{2}{|c|}{ Model }} & \multicolumn{2}{|c|}{$\begin{array}{c}\text { Unstandardized } \\
\text { Coefficients }\end{array}$} & \multirow[b]{2}{*}{$\mathrm{t}$} & \multirow[b]{2}{*}{ Sig. } & \multicolumn{2}{|c|}{$\begin{array}{c}\text { Collinearity } \\
\text { Statistics }\end{array}$} \\
\hline & & B & Std. Error & & & Tolerance & VIF \\
\hline \multirow[t]{6}{*}{1} & (Constant) & 433,264 & 24,848 & 17,437 & ,000 & & \\
\hline & $\mathrm{AG}$ &,- 296 &, 136 & $-2,167$ & ,034 & ,589 & 1,699 \\
\hline & $\mathrm{SG}$ &, 494 &, 240 & 2,060 & 044 &, 617 & 1,621 \\
\hline & NPM & $-24,000$ & 12,096 & $-1,984$ & ,052 & 674 & 1,484 \\
\hline & $\mathrm{CR}$ & $-164,499$ & 10,587 & $-15,537$ & ,000 & ,647 & 1,546 \\
\hline & DER & $-99,768$ & 11,603 & $-8,598$ &, 000 & ,463 & 2,160 \\
\hline
\end{tabular}

Uji autokorelasi bertujuan untuk menguji apakah model persamaan regresi terdapat korelasi antara kesalahan pengganggu pada periode $\mathrm{t}$ dengan kesalahan pengganggu pada periode t-1 (sebelumnya) (Ghozali, 2011). Berdasarkan hasil tabel7 ,Durbin-Watson didapatkan nilai dL sebesar 1,438 dan nilai dU sebesar 1,767. Sementara itu, hasil uji Durbin-Watson menunjukkan bahwa nilai DW sebesar 1,981. Model persamaan regresi dalam penelitian ini tidak terjadi gejala autokorelasi karena nilai DW lebih besar dari batas atas (dU) 1,767 dan kurang dari 2,233 (4-dU).

Tabel 7

Summary

\begin{tabular}{|l|r|r|r|r|r|}
\hline Model & R & R Square & \multicolumn{1}{|c|}{$\begin{array}{c}\text { Adjusted R } \\
\text { Square }\end{array}$} & $\begin{array}{l}\text { Std. Error of } \\
\text { the Estimate }\end{array}$ & $\begin{array}{c}\text { Durbin- } \\
\text { Watson }\end{array}$ \\
\hline 1 &, $915^{\mathrm{a}}$ &, 837 &, 823 & 21,60263 & 1,981 \\
\hline
\end{tabular}

Uji heteroskedastisitas bertujuan untuk menguji apakah dalam model regresi terjadi ketidaksamaan variance dari residual suatu pengamatan ke pengamatan yang lain (Ghozali, 2011). Berdasarkan gambar 1, grafik scatterplot menunjukkan bahwa titik-titik tersebar secara acak (tidak berpola) baik di atas maupun di bawah angka 0 (nol) pada sumbu Y. Oleh kerena itu, dapat disimpulkan bahwa model persamaan regresi yang digunakan dalam penelitian ini telah memenuhi asumsi homoskedastisitas

Pengaruh Asset Growth, Sales Growth, Net Profit Margin, Current Ratio dan Debt To Equity Ratio terhadap Dividend Payout Ratio pada Perusahaan yang Termasuk dalam Indeks Lq 45 Tahun $2013-$ 2016 


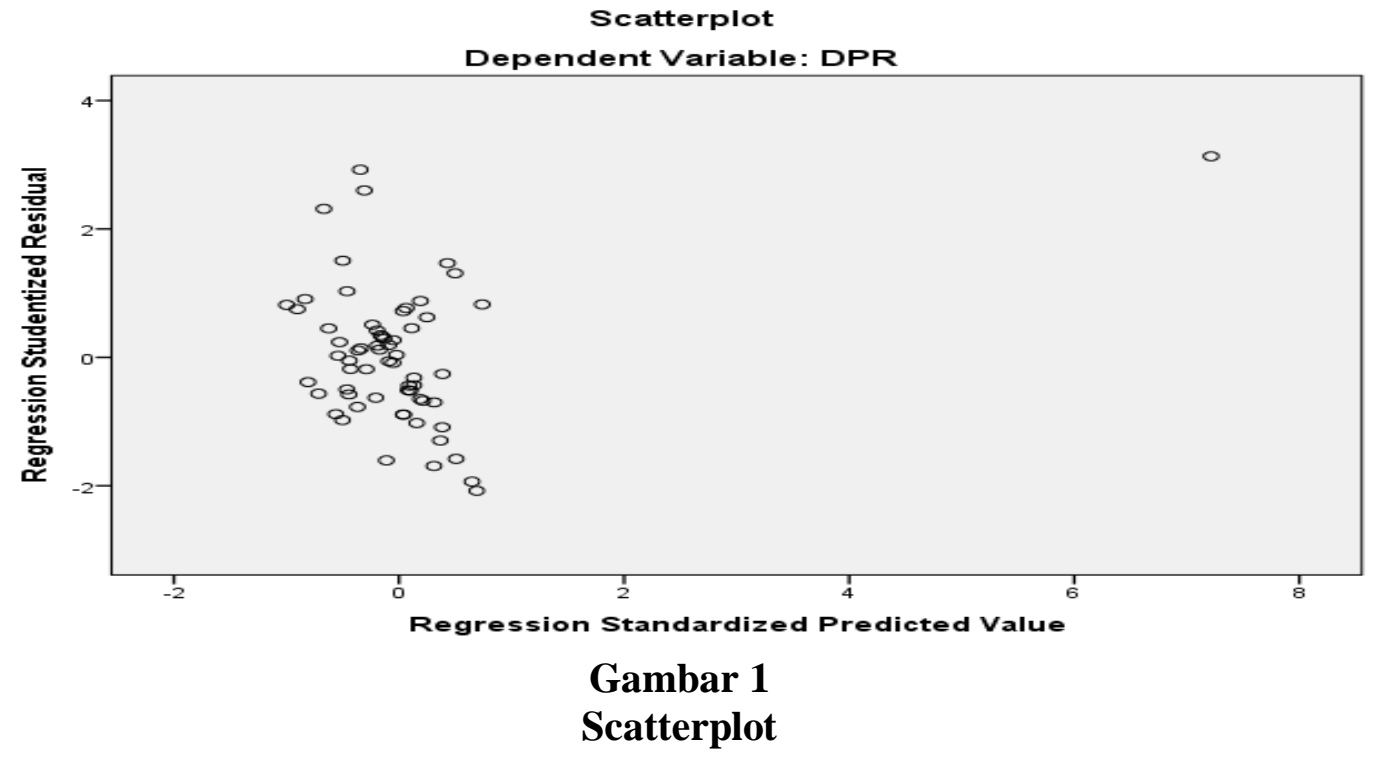

Dalam penelitian ini model persamaan regresi linier berganda dengan data panel yang disusun untuk mengetahui pengaruh Aset Growth, Sales Growth, NPM, $C R$ dan DER (sebagai variabel independen) terhadap Dividen Payout Rate (DPR) (sebagai variabel dependen) hasil uji regresi berganda dapat dilihat pada tabel 8 berikut ini:

Tabel 8

Hasil Uji Regresi Berganda

\begin{tabular}{|c|c|c|c|c|c|c|}
\hline \multirow{2}{*}{\multicolumn{2}{|c|}{ Model }} & \multicolumn{2}{|c|}{$\begin{array}{l}\text { Unstandardized } \\
\text { Coefficients }\end{array}$} & \multirow{2}{*}{\begin{tabular}{|c|}
$\begin{array}{c}\text { Standardize } \\
\mathrm{d} \\
\text { Coefficients }\end{array}$ \\
Beta \\
\end{tabular}} & \multirow[b]{2}{*}{$\mathrm{T}$} & \multirow[b]{2}{*}{ Sig. } \\
\hline & & B & Std. Error & & & \\
\hline 1 & (Constant) & 433,264 & 24,848 & & 17,437 & ,000 \\
\hline & $\mathrm{AG}$ &,- 296 & ,136 &,- 150 & $-2,167$ &, 034 \\
\hline & SG & ,494 & ,240 & ,139 & 2,060 & ,044 \\
\hline & NPM & $-24,000$ & 12,096 &,- 128 & $-1,984$ &, 052 \\
\hline & $\mathrm{CR}$ & $-164,499$ & 10,587 & $-1,024$ & $-15,537$ &, 000 \\
\hline & $\overline{\text { DER }}$ & $\begin{array}{l}-99,768 \\
\end{array}$ & 11,603 &,- 670 & $-8,598$ & ,000 \\
\hline
\end{tabular}

Sumber : Output SPSS

Berdasarkan hasil analisis regresi berganda dengan data panel pada tabel 8di atas dapat diperoleh koefisien untuk variabel bebas $\mathrm{AG}=-0,296, \mathrm{SG}=0,494 \mathrm{dan}$ $\mathrm{NPM}=-24, \mathrm{CR}=-164,499, \mathrm{DER}=-99,768$ konstanta sebesar 433,264 sehingga model persamaan regresi yang diperoleh:

$$
Y_{\text {it }}=433,264-0,296 X_{1 i t}+0,494 X_{2 i t}-24 X_{3 i t}-164,499 X_{4 i t}-99,768 X_{i t}+\mu
$$

Dimana : $\mathrm{Y}=$ Dividen Payout Ratio; $\beta_{0}=$ konstanta; $\beta_{1}=$ koefisien Regresi Aset Growth; $\beta_{2}=$ koefisien Regresi Sales Growth; $\mathrm{X}_{1}=$ Aset Growth (AG); $\mathrm{X}_{2}=$ Sales Growth $(S G) ; \beta_{3}=$ koefisien Regresi Net Profit Margin; $\mathrm{X}_{4}=$ Current Ratio $(\mathrm{CR}) ; \mathrm{X}_{3}=$

Pengaruh Asset Growth, Sales Growth, Net Profit Margin, Current Ratio dan Debt To Equity Ratio terhadap Dividend Payout Ratio pada Perusahaan yang Termasuk dalam Indeks Lq 45 Tahun 2013 2016 
Net Profit Margin (NPM); $\beta_{4}=$ koefisien Regresi CR; $\mathrm{X}_{5}=$ Debt To Equity Ratio ( DER); $\beta_{5}=$ koefisien Regresi DER; $\mathrm{i}=$ Unit cross section; $\mathrm{t}=$ Periode waktu; $\mu=$ error

\section{Hasil Uji Hipotesis}

Pengujian hipotesis dalam penelitian ini dilakukan dengan menggunakan teknik analisis regresi linier berganda. Peneliti menggunakan $\alpha=5 \%$ untuk menilai signifikansi hubungan antara setiap variabel. Uji F digunakan untuk mengetahui apakah variabel independen yang terdapat dalam persamaan regresi secara bersamasama mempengaruhi variabel dependen. Hasil perhitungan uji $\mathrm{F}$ untuk model regresi yang diteliti dapat dilihat pada tabel 9 berikut :

Tabel 9

ANOVA $^{\mathrm{a}}$

\begin{tabular}{|c|c|c|c|c|c|c|}
\hline \multicolumn{2}{|c|}{ Model } & $\begin{array}{c}\text { Sum of } \\
\text { Squares }\end{array}$ & df & Mean Square & $\mathrm{F}$ & Sig. \\
\hline \multirow[t]{3}{*}{1} & Regression & 139059,231 & 5 & 27811,846 & 59,596 &, $000^{b}$ \\
\hline & Residual & 27067,068 & 58 & 466,674 & & \\
\hline & Total & 166126,299 & 63 & & & \\
\hline
\end{tabular}

Uji Anova atau F test sebesar 59,596 dengan tingkat probabilitas 0.000 (signifikan ). Karena probabilitas jauh lebih kecil daripada 0.05 maka model regresi dapat digunakan untuk memprediksi DPR atau dapat dikatakan Asset Growth, Sales Growth, NPM, CR dan DER secara bersama-sama berpengaruh terhadap Dividen payout ratio pada perusahaan Non Keuangan yang LQ 45 yang terdaftar di Bursa Efek Indonesia (BEI) periode 2013-2016. Dengan menggunakan tingkat keyakinan $95 \%$ untuk $\alpha=5 \%$ dengan derajat kebebasan $(\mathrm{df})=58$ maka $t_{\text {tabel }}$ diperoleh sebesar 2,002 .

\section{Pengujian hipotesis pertama}

\section{H: Asset Growth BerpengaruhNegatif Terhadap Deviden Payout Ratio}

Dari tabel 8 hasil uji parsial ( $\mathrm{t}$ - test), variabelAsset Growth (AG) memiliki pengaruh signifikan negatif terhadap devidend payout ratio. Hal ini dapat dilihat dari probabilitas signifikansi untuk AG sebesar 0.034 yang lebih kecil daripada 0.05 dan karena nilai $\mathrm{t}$ statistik $>\mathrm{t}$ tabel. Oleh karena itu hipotesis $\mathrm{H} 1_{\mathrm{a}}$ diterima. Hasil penelitian ini sejalan dengan teori agensi, bahwa Hasil penelitian ini didukung oleh Silviana (2014 ) dimana aset growth memberikan pengaruh negative terhadap deviden payout rasio. Menurut Brigham dan Houston (2010) dalam Silviana, dkk. (2014), Asset Growth merupakan rasio yang digunakan untuk mengetahui peningkatan pertumbuhan total aset dari tahun ke tahun. Pertumbuhan total aset sangat berpengaruh dalam penentuan kebijakan deviden karena semakin besar pertumbuhan aset perusahaan, maka perusahaan akan lebih memilih menggunakan laba yang diperoleh untuk membiayai ekspansi dari pada menggunakannya untuk membayar deviden. Pertumbuhan perusahaan yang tinggi akan membuat perusahaan 
menggunakan sebagian besar labanya untuk membiayai pertumbuhannya, sehingga laba yang tersisa untuk dibagikan sebagai deviden kepada para pemegang saham akan semakin kecil.

\section{Pengujian hipotesis kedua}

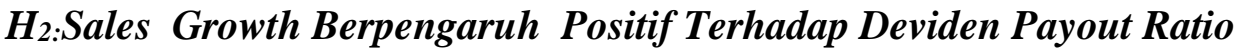

Hasil uji parsial didapatkan bahwa Sales Growth berpengaruh signifikan positif terhadap deviden payout ratio . Dilihat dari probabilitas signifikansi untuk Sales Growth sebesar 0.044 dimana probabilitas lebih kecil daripada 0.05 dan nilai $t$ statistik > t tabel. Oleh karena itu hipotesis $\mathrm{H} 2{ }_{\mathrm{a}}$ diterima Sales growth merupakan variabel yang secara statistik berpengaruh terhadap dividend payout rate, Semakin tinggi sales growth, semakin efektif perusahaan dalam penggunaan aktivanya untuk menghasilkan total penjualan bersih. Semakin efektif perusahaan menggunakan aktiva untuk menghasilkan penjualan bersih menunjukkan semakin tinggi dividen yang dibagikan. Hasil ini sejalan dengan penelitian Rafique (2012) yang menguji pengaruh sales growth terhadap DPR dimana hasil penelitiannya menunjukkan hasil bahwa sales growth berpengaruh signifikan positif terhadap DPR.

\section{Pengujian hipotesis ketiga}

\section{H3: Net Profit Margin Berpengaruh Positif Terhadap Deviden Payout Rate}

Hasil uji parsial didapatkan bahwa Net Profit Margin tidak berpengaruh positif terhadap deviden payout rate . Dilihat dari probabilitas signifikansi untuk NPM sebesar 0.052 dimana probabilitas lebih besar daripada 0.05 dan nilai $t$ statistik < t tabel. Oleh karena itu hipotesis $\mathrm{H} 3_{\mathrm{a}}$ ditolak . Hasil penelitian ini sesuai dengan penelitian Arifin dan Asyik ( 2015) dimana profitabilitas tidak berpengaruh signifikan terhadap kebijakan deviden .Hal ini terlihat dari salah satunya dimana meskipun laba tahun 2015 pada PT. Unilever Indonesia Tbk ( UNVR) mengalami penurunan 1,92 \% UNVR tetap membagikan devidennya. UNVR kerap menetapkan hampir seluruh labanya menjadi deviden.Payout dividen kali ini nyaris $100 \%$ (http://investasi.kontan.co.id/15/06/2016)

\section{Pengujian hipotesis keempat}

\section{H4:Current Ratio Berpengaruh Negatif Terhadap Deviden Payout Ratio}

Hasil uji parsial didapatkan bahwa Current ratio berpengaruh signifikan negatif terhadap deviden payout ratio . Dilihat dari probabilitas signifikansi untuk Current ratio sebesar 0.000 dimana probabilitas lebih kecil daripada 0.05 dan nilai $t$ statistik > t tabel. Oleh karena itu hipotesis $\mathrm{H} 4$ aditerima. Hal ini didukung oleh rata - rata current ratio yaitu 232, 68 untuk industri non keuangan yang tercantum dalam indeks LQ 45 dimana Perusahan - perusahaan ini mempunyai likuiditas yang cukup tinggi . Hal ini terlihat pada tabel 1 dimana pada tahun 2015 rata - rata current ratio naik menjadi 293,58 \% dan deviden payout ratio menjadi 4,72 \% dan pada tahun 2016 rata - rata current ratio turun menjadi $210,59 \%$ dan deviden payout ratio menjadi $67,83 \%$. Hal ini didukung juga oleh penurunan pertumbuhan aset lancar rata - rata industri manufaktur.

\section{Pengujian Hipotesis Kelima}

Pengaruh Asset Growth, Sales Growth, Net Profit Margin, Current Ratio dan Debt To Equity Ratio terhadap Dividend Payout Ratio pada Perusahaan yang Termasuk dalam Indeks Lq 45 Tahun 2013 2016 


\section{H5: Debt To Equity Berpengaruh Negatif Terhadap Deviden Payout Ratio}

Hasil uji parsial didapatkan bahwa Debt To Equity ratio berpengaruh negative signifikan terhadap deviden payout ratio. Dilihat dari probabilitas signifikansi untuk Sales Growth sebesar 0.000 dimana probabilitas lebih kecil daripada 0.05 dan nilai $\mathrm{t}$ statistik $>\mathrm{t}$ tabel. Oleh karena itu hipotesis $\mathrm{H}_{5 \mathrm{a}}$ diterima .Hasil ini sejalan dengan penelitian Elissya ( 2013 )yang menjelaskan bahwa DER berpengaruh negative signifikan terhadap DPR.

Analisis determinasi dilakukan untuk mengetahui persentase sumbangan pengaruh variabel bebas terhadap variabel terikat. Hasil koefisien determinasi $\left(\mathrm{R}^{2}\right)$ yaitu sebagai berikut:

Tabel 10

\begin{tabular}{|l|c|r|r|r|r|}
\hline \multicolumn{1}{|c|}{ Model Summary } \\
Model & R & R Square & $\begin{array}{c}\text { Adjusted R } \\
\text { Square }\end{array}$ & $\begin{array}{c}\text { Std. Error } \\
\text { of the } \\
\text { Estimate }\end{array}$ & $\begin{array}{c}\text { Durbin- } \\
\text { Watson }\end{array}$ \\
\hline 1 &, $915^{\text {a }}$ &, 837 &, 823 & 21,60263 & 1,981 \\
\hline
\end{tabular}

Berdasarkan tabel 10 di atas, diperoleh nilai $R$ Square yaitu sebesar 0.837. Hal ini menunjukkan bahwa besar pengaruh Asset Growth, Sales Growth, NPM, CR dan DER secara bersama-sama berpengaruh terhadap Dividen payout ratio adalah sebesar $83,7 \%$ sedangkan sebesar $16.3 \%$ dipengaruhi oleh faktor lain diluar penelitian ini.

\section{SIMPULAN}

Berdasarkan hasil analisis data yang telah dilakukan, dapat ditarik kesimpulan bahwa variabel Asset Growth, Sales Growth, Net Profit Margin, Current ratio (CR), Debt to Equity ratio ( DER) mempunyai pengaruh yang signifikan terhadap dividend payout ratio pada industri non keuangan yang tercantum dalam indeks LQ 45 di Bursa Efek Indonesia dengan tingkat signifikansi $5 \%$. Kelima variabel bebas tersebut mampu mempengaruhi deviden payout ratio sebesar 83,7 \% sedangkan sisanya sebesar 16,3 \% dipengaruhi variabel lain yang tidak termasuk dalam penelitian ini.Secara partial hanya net profit margin yang tidak mempunyai pengaruh secara signifikan. Asset growth, Current ratio dan Debt to Equity mempunyai pengaruh signifikan negatif, sedangkan Sales Growth mempunyai pengaruh signifikan positif terhadap devident payout ratio.

\section{DAFTAR PUSTAKA}

Adisetiawan, R,. 2011, Analisa Pengaruh Variabel-variabel Fundamental terhadap Returm Saham LQ45, Jurnal Ilmiah Universitas Batanghari, 11(2), 21-31, 1(1), 10-17

Ahmadi, dan Alhudhori, M., 2017, Pengaruh Total Asset Turnover (TATO) dan Return on Equity (ROE) Terhadap Harga Saham pada Industri Asuransi di Bursa Efek Indonesia, EKSIS: Jurnal Ilmiah Ekonomi dan Bisnis, 6(2): 5866 
Arifin , Samsul dan Nur Fadjrih Asyik . 2015 .Pengaruh Profitabilitas, Likuiditas, Growth Potential dan Kepemilikan Manajerial Terhadap Kebijakan deviden . Jurnal Ilmu \& Riset Akuntansi Vol 4 No. 2 . Penerbit STIESIA Surabaya

Baert, Lieven dan Rudi Vander Vennet. 2009. "Bank ownership, firm value, and firm capital structure in Europe, " JIEL Classification

Charlina Silviana dkk. 2014. Analisis Variabel-Variabel Yang Mempengaruhi Kebijkan Deviden (Studi Pada Saham Indeks LQ-45 di BEI periode 20102012), Jurnal Administrasi Bisnis (JAB), Vol. 15 No.1 Oktober.

Deitiana, Tita .2013 . Pengaruh Current Ratio, return On Equity dan Total Asset Turn Over Terhadap Devident Payout Ratio dan Implikasi Pada Harga Saham Perusahaan LQ 45 . Jurnal Bisnis dan Akuntansi Vol 15 No 1 Juni 2013. STIE Trisakti.

Elissya 2013. Analisis Faktor - Faktor yang mempengaruhi kebijakan deviden pada Perusahaan Manufaktur yang tercatat di BEI Pada Periode 2007 -2011. Jurnal Fakultas Ekonomi dan bisnis . Universitas Lampung.

Ghozali, I. 2011. Aplikasi Analisis Multivariate dengan Program SPSS. Semarang: Badan Penerbit Universitas Diponegoro.

Indrawati , T dan Suhendro 2006. Determinasi Capital Structure Pada Perusahaan Manufaktur di Bursa Efek Jakarta Periode 2000 - 2004 , Jurnal Akuntansi dan Keuangan Indonesia Vol . 3 No 1. Atmajaya.

Ismiyanti, Fitri dan Mamduh Hanafi. 2004. "Struktur Kepemilikan, Risiko, dan Kebijakan Keuangan: Analisis Persamaan Simultan, ’Jurnal Ekonomi dan Bisnis Indonesia, Vol.19, No.2

http://investasi.kontan.co.id/news/dividen-unvr-naik-meski-laba-turun/15juni 2016

Kadir , Abdul . 2010 . Analisis Faktor - Faktor Yang Mempengaruhi Kebijakan Deviden Pada Perusahaan Credit Agencies Go Publik Di Bursa Efek Indonesia. Jurnal Managemen dan akuntansi Volume 11 Nomor 1 . STIE Banjarmasin.

Kasmir.2010.Analisis Laporan Keuangan .Jakarta . PT Raja Grafindo Persada.

Kraft, Jackie, Yiping Qu, Francesco Quatraro, dan Jacques Laurent Ravix. 2013. "Corporate governance, value and performance of firms, "University of Nice Sophia Antipolis

Laksono, Bagus. 2006. Analisis Pengaruh Return on Assets, Sales Growth, Asset Growth, Cash Flow dan Likuiditas terhadap Dividend Payout Ratio (Perbandingan Pada Perusahaan Multi National Companay (MNC) dan Domestic Corporation yang Listed di Bursa Efek Jakarta Periode 20022004). Tesis. Semarang: Program Pascasarjana UNDIP.

Nadjibah .2008. Analisis Pengaruh Asset Growth, Size, Cash Ratio dan Return On Asset Terhadap Divident Payout Ratio . Tesis .Semarang : Program Pascasarjana UNDIP

Nitta, Keisuke. 2006. "Does dividend policy enhance shareholder value," Financial Research Group.

Prihantoro. 2003. Estimasi Pengaruh Devidend Payout Ratio Pada Perusahaan Publik di Indonesia,Jurnal Ekonomi dan Bisnis, No. 1 Jilid 8. 
Rafique, Mahira. 2012.Factors affecting dividend payout: evidence from listed non financial firms of Karachi stock exchange,Bussiness Management Dynamics, $3,41-83$

Subramanyam, K.R.\& Wild, John J . Analisis Laporan Keuangan. Buku 1 Edisi 10 (terjemahan) .Jakarta : Salemba Empat

Weston .JF \&T.E Copeland 2008. Manajemen Keuangan . Binarupa Aksara. Jakarta

Yasa dan Wirawati .2016 .Pengaruh Net Profit Margin,Current ratio, dan Debt To Equity ratio pada Dividend Payout ratio. E - Jurnal Akuntansi Universitas Udayana VOL 16 .2 Agustus 2016 .

Pengaruh Asset Growth, Sales Growth, Net Profit Margin, Current Ratio dan Debt To Equity Ratio terhadap Dividend Payout Ratio pada Perusahaan yang Termasuk dalam Indeks Lq 45 Tahun $2013-$ 2016 